$\mathrm{E}$

$\sim$

$=\frac{1}{7}$

$r$

$1-$

I

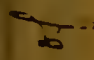

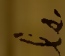

3

$=$

$\div$

$\frac{5}{5}$

2

2

క

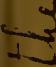

$\gamma$

i

$+$

$=$

$\checkmark$

$\overline{1}$

3

$f$

?

3

ذِ

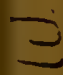




\section{Why Not Save the Marine Mammals of the Pacific?*}

By Barton Warren Evermann.

Director, Museum California Academy of Sciences

The biggest animals in the world are found in the Pacific; and that seems as it should be and entirely proper, for is not the Pacific the biggest ocean in the world? Just how many kinds of whales and other marine mammals there are in the Pacific we really do not know; and that is highly improper, not to say disgraceful, for we surely ought to know.

The animals I refer to are the fur seals, sea lions, porpoises, elephant seals, walruses, whales and the like. Recently I examined all the available literature at hand and was able to make up a list of the species of marine mammals of the North Pacific. The list contains 9 baleen whales, 5 sperm whales, 12 porpoises, killers and dolphins, or a total of 26 cetaceans; and 1 bear, 2 sea otters, 4 fur seals, 10 sea lions and liarbor seals, and 1 walrus, or a total of 18 carnivores; or 44 in all.

The following is a list of the species that we may recognize for present purposes:

\section{CETACEANS.}

Balæniclæ. Baleen whales.

1. Balæna sieboldi Gray. (Pacific Right whale; Siebold's Baleen whale.)

2. Ralæna mysticetus Linnæus. (Bowhead whale; Arctic Right whale.)

3. Balæna kuzira (Gray). (Gray's Japanese Baleen whale.)

4. Rhachinectes glaucus (Cope). (California Gray whale; Gray Baleen whale.)

* An arlvance paper prepared for the First Pan-Pacific Commercial Confcrence.
5. Megaptera nodosa Cope. (Pacific Humpback whale.)

6. Balænoptera borealis Lesson. (Sei whale; Rorqual; Sardine' iwliale.)

7. Balænoptera davidsoni Scammon. (Davidson's Lesser Rorqual.)

8. Bálænóptera velifera Cope. (Pacific Finback whale; Oregon Finback whale; Large Finback whale.) : ....

9. Balænopterá sulfureus (Cope). (Pacific Stulphur - bottom whale; Blue whale.)

Physeteridæ. (Sperm whales.)

10. Physeter macrocephalus Linnæus. (Sperm whale; Cachalot Sperm whale.)

11. Cogia breviceps (Blainville). Pigmy Sperm whale.)

12. Ziphius grebnitzkii Stejneger. (Grebnitzky's Two-tootherl whale.)

13. Mesoplodon stejnegeri True. (Stejneger's Sperm whale.)

14. Berardius bairdi Stejneger. (Baird's Beaked w ha l. e ; Baird's Sperm whale.)

Delphinidx. (Porpoises, Killers, etc.)

15. Phocæna phocæna (Linincus). (Bay Porpoise; Common Porpoise.)

16. Phocæna dalli True. (1)all's Porpoise.)

17. Orcinus rectipinna (Cope). (Straight-finned Killer.)

18. Orcinus ater (Cope). (Pacific Killer; Black Killer: Orca.)

19. Globiocephalus s c a m m o $\mathrm{i}$ Cope. (Scammon's Blackfish.) 
20. Grampus griseus (Cuvier). (Common Grampus; Gray Blackfish.)

21. Lagenorhynchus thicolea Gray. (Gray's Bottle-nosed whale.)

22. Lagenorhynchus obliquidens Gill. (Striped Porpoise; Gill's Bottle-nosed whale.)

23. Delphinius delphis Linnæus. (Common Dolphin.)

24. Tursiops gilli Dall. (Cowfish; Gill's Dolphin.)

25. Lissodelphis borealis (Peale). (Northern Right Whale Porpoise; Pacific Ocean Dolphin.)

26. Prodelphinus lon $\mathrm{g}$ i $\mathrm{r}$ o s $\mathrm{t} \mathrm{r}$ is (Gray). (Long-nosed Dolphin.)

\section{CARNIVORES.}

Ursidæ

FISSIPEDIA.

27. Thalarctos maritimus Phipps. Mustelidæ. (Polar Bear.)

28. Latax lutris (Linnæus). Sea Otter.)

29. Latax lutris nereis Merriam. (Southern Sea Otter.)

Otariidæ. PINNIPEDIA.

30. Eumetopias stelleri (Lesson). (Steller's Sea Lion.)

31. Zalophus californianus (Lesson). (California Sea Lion.)

32. Callorhinus alascensis Jordan \& Clark. (Alaska Fur Seal.)

33. Callorhinus kurilensis Jordan \& Clark. (Japanese Fur Seal.)

34. Callorhinus ursinus Linnæus. (Russian Fur Seal.)

35. Arctocephalus townsendi Merriam. (Guadalupe Fur Seal.) Odobenidæ.

36. Odobenus obesus Illiger. (IValrus.)
Phocidae.

37. Macrorhinus angustirostris Gill. (Northern Elephant Seal.)

38. Erignathus barbatus (Fabricius). (Bearded Seal.)

39. Histriophoca fasciata (Zimm.). (Ribbon Seal.)

40. Phoca grœnlandica Fabricius. (Harp Seal.)

41. Phoca hispida Schreber. (Ringed Seal.)

42. Phoca richardi (Gray). (Harbor Seal; Richard's Harbor Seal.)

43. Phoca richardi geronimensis Allen. (California Harbor Seal; Leopard Seal.)

4t. Phoca stejnegeri Allen. (Stejneger's Harbor Seal.)

Here is a list of forty-four species oi large animals; included among them are the largest animals living in the world today. Whether there really are forty-four different species we do not know; that number may be too great but more probably it is not large enough. We do not know-and that is the important consideration now-the largest and in many respects the most interesting animals in existence, and we are compelled to admit we know less as to the number of species than we know of almost any other group.

Nor do we know very much about the geographic distribution of many of these animals. To be sure, we know something of the abundance and distribution of the three northern species of fur seal and the northern sea otter. and the sea lions, but of the whales, porpoises and the southern sea otter and the Guadalupe fur seal scarcely anything.

And of the life histories of these wonderful animals we know scarcely more than Scammon knew more than a half century ago. Their food and 
feediug habits, migrations, breeding seasons and places, period of gestation, rate of growth, age at maturity, natural and other enemies,-these are but a few of the many things in the life histories of these animals about which little is known, but which we would very much like to know.

Take, for example, the whales. It would seem that animals as big and conspicuous any interesting as whales ought to be pretty well known to the naturalists at least, if not to the layman; but we really know very little about them. We do not even know what species occur on the Pacific Coast of North America. A good illustration of this incompleteness of knowledge is the Sei whale or Japanese Sardine whale. In his Monograph of the Pacific Cetacea, Dr. Roy C. Andrews said, in 1916: "The occurrence of this species in the North Pacific was unknown to the scientific world until my work in Japan during 1912." $\mathrm{He}$ then found it the most abundant of the large Cetaceans in Japanese waters where it constitutes the greater part of the summer fishery. While he believed it should occur on the west coast of North America, he knew of no trustworthy record and says that further proof must be forthcoming before the appearance of this species along the west coast of America can be considered as established.

Recently I was informed by Mr. A. Ciosney, Bookkeeper of the Moss Landing Station of the California Sea Products Company, that the station at Kyuquot, Vancouver Island, took 60 Sei whales in 1918, and that several more were taken the same year by other stations in British Columbia in 1918. Mr. Gosney was at these stations in 1918, is quite familiar with the Sei whale, and is certain of the identification. And a 40-foot example of this species was taken off Santa Cruz by the Moss Landing Station September 9, 1920. Mr. Gosney says the Sei most resembles the Finback, from which it is readily distinguished by the longer dorsal fin; the hair inside the mouth is soft, whitish and about nine inches long, while in the Finback it is coarse, dark gray and only about six inches long.

Mr. Gosney does not know of any American record before 1918. Captain Dedrick confirms Mr. Gosney's statements.

The commercial fisheries of the North Pacific can be properly understood and regulated only in the light of pretty full knowledge of the Cetaceans and seals of the various kinds. It is important to know just what relation the whales, sea lions, harbor seals and porpoises sustain to the salmon, the sardine, the herring, and the cod. The relation of the California sea lion and Steller's sea lion to the salmon fisheries has long been a moot question. Conclusive study of the question has never been made, and no one is in a position to say from his own knowledge just what laws should be enacted regarding those species. The same is true of the whales. What we know or believe regarding their feeding habits is of the most general character. Only a few days ago I was told that an examination of the stomach contents of a Humpback whale recently brought in to the Moss Landing Whaling Station of the California Sea Products Company yielded 1500 to 3000 pounds of sardines, besides a miscellaneous lot of smelt, anchovies, shrimps, and squids. In the stomach of a sperm whale were found a 10-foot shark, a piece of fur-seal skin, and a bunch of fishhooks!

These are surprising statements, especially that about the 10 -foot shark. They call attention to the necessity for 
comprehensive study of the feeding habits of whales and their relation to the fisheries. The sardine fishermen of Monterey Bay, as well as those in Norway, claim tliat the whales herd the sardines inshore and are therefore beneficial to the sardine fishery; they therefore object to the killing of whales. The whaling station at Moss Landing on Monterey Bay offers exceptional facilities ior investigation of this question As a matter of fact we know too little about the relation of most of the forty odd species of marine mammals to the commercial fisheries to enable us to advise intelligently as to laws for their protection, regulation, or destruction.

W'e do know that, because of the great commercial value of their pelts, the three species of fur seal and the two of sea otter should be fully protected. We know that no more of any of those species should be killed anrually than can be spared without in the least militating against the maintenance of those valuable species at the maximum number and efficiency. Whether this statement can be made regarding any others is doubtful. Some of them, as the whales, have considerable commercial value. Others, as the sea lions, have some commercial value. Still others, as the dolphins and harbor seals, possess as yet only slight commercial value. What the effect on the fisheries would be if their numbers should greatiy increase, or greatly decrease, can not safely be prelicted; the known facts are not adenirate for a rlecided answer; only long-continued. painstaking investigation can tell us what the answer will be.

But of this one thing we can ise very sure, namely: none of these species should be put in danger of extinction or even serious diminution as to individuals until we do know whether, on the whole, it is more harmful than use- ful. And if investigation should show a species to be on the whole more harmful than useful, even then we should give that species some protection. We do not want any animal to become extinct if we can help it. Even enough rattlesnakes should be saved to prevent the species from disappearing from the earth. Pure natural history has some rights that must be respected.

Several very interesting and important animals have already been permitted to become extinct, some directly through man's activities, others through his indifference. The North Pacific can furnish more than one illustration of this fact. The most interesting and regretful is, perhaps, that of Steller's Sea-Cow (Rytina gigas). This remarkable animal was first discovered in 1741 by Captain Vitus Bering when his ship was wrecked on the island which now bears his name. George William Steller was the surgeon and naturalist of Bering's ship and it is to him we owe practically all we know about the sea cow in life.

At the time of its discovery this large marine mammal was abundant about Bering Island. Steller states that he saw them in great herds feeding on the kelp and other seaweeds that grow luxuriantly in shallow water about the Commander Islands. It was soon discovered that the flesh was excellent human food and the men killed many of them for that purpose. When, in 1743 , the news of the discovery of Bering Island reached Kamchatka, several expeditions were fitted out to hunt the sea cow and the various fur-bearing animals such as the sea otter, fur seal, the blue fox which also were found there; and very soon whaling ressels began to stop there to lay in a supply of sea-cow meat for food. So great was the destruction wrought by these whalers and fur hunters that by 1754 . 
only thirteen years after its discovery the sea cow was practically exterminated.

Steller's sea cow, $2+$ to 30 feet long when fully grown and weighing three or four tons, was a gregarious, stupid. sluggish animal, comparatively helples: and unable to protect itself by diving. It was therefore an easy matter to exterminate it. But it would have been just as easy to protect it, and that is the important point-a commercially very valuable animal that could so easily have been conserved while at the same time yielding annually a large amount of desirable human food by restricting the killing to surplus males.

According to Dr. L. Stejneger the last remaining individual was killed in 1768 , and Rytina went to join the mammoth and the mastodon and the host of other great animals of the past where they were joined in 1844 by the Great Auk, and by the Passenger Pigeon in 1916, and where they will ere long be joined by the Elephant Seal, the Sea Otter, the Walrus and many other species unless the world awakes to an appreciation of the inminence of the danger.

Another example is that of the Guada . lupe fur seal at one time abundant on Grtadalupe Island and other islands off the coast of Mexico and California. So abundant was it that more than 200,000 were taken at the Farallons in 1808-1811.

This slaughter apparently soon resulted in the complete extermination of the species on the California coast. but a few survived on some of the southern islands. In 1892 Dr. Chas. H. Townsend and Mr. A. IV. Anthony visited Guadalupe Island when they saw at least one specimen which they killed but were unable to secure. Since then the species has been thought to be practically extinct. Recently a single individual was captured alive near San Diego, and it is now believed a few may still exist about Guadalupe and others of the small islands off the coast of Lower California.

The southern sea otter also was abundant at one time on the California and Mexican coast. Old Spanish records state that 9729 sea otters were taken in 1803 to 1806 . A few have been seen in Monterey Bay and elsewhere as late as 1914.

In order that these vanishing species may be saved from extinction a careful study should be made to determine where they now occur and in what num?ber and as much as possible regarding their habits. This investigation should be participated in by the United State: and Mexico and should be conducted by the Committee on Conservation of Marine Life of the Pacific of the Committee on Pacific Investigations of the Division of Foreign Relations of the National Research Council. Following the field investigations a treaty. should be entered into by the United States and all other countries concerned for the protection of these and all other marine nammals of the Pacific.

One of the best things the Pan- $\mathrm{Pa}$ cific Union can do is to use its good offices with the various countries bordering on the Pacific to bring about such an international treaty. In no other way can these valuable aninals be saved.

And when such a convention is negotiated it would be well if it could include not only marine mammals but all other marine life of the high seas such as the fishes, turtles, and sea birds 
Photomount

Pamphlet

Binder

Gaylord Bros.

Makers

Syracuse, N. $\mathbf{Y}$.

PAT. JNH 21, 1908
MCZ EANST MAYR LIBRAAY

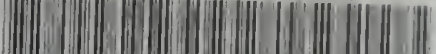

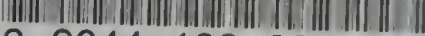

$32044128 \quad 397163$ 
